\title{
11-12 KLASIŲ MOKINIŲ SVEIKATOS RAŠTINGUMAS IR RŪKYMAS
}

\author{
Olga Ubartienė, Genė Šurkienė \\ Vilniaus universiteto Medicinos fakulteto Sveikatos moksly institutas
}

Raktažodžiai: sveikatos raštingumas, rūkymas, paaugliai, mokiniai.

\section{Santrauka}

Sveikatos raštingumas - svarbi ir dar mažai tyrinèta visuomenès sveikatos sritis. Ribotas sveikatos raštingumas susijęs su blogesne sveikatos būkle ir didesnèmis sąnaudomis. Paauglystès laikotarpiu susiformavusi sveikatos elgsena turi įtakos suaugusiuju sveikatos rezultatams, todèl svarbu pletoti ir vertinti visuomenès sveikatos intervencijas, kurios skatintų geresni paauglių ir jaunimo sveikatos informacijos supratimą ir jos panaudojimą. Tyrimo tikslas. Nustatyti pagrindinių ir vidurinių mokyklų 11-12 bei gimnazijų III-IV (toliau - 11-12; III-IV) klasių mokinių rūkymo ir sveikatos raštingumo sąsajas. Tyrimo metodai. Anoniminès anketinès apklausos metodu buvo apklausti 1038 Lietuvos mokyklų 11-12; III-IV klasių mokiniai. Sveikatos raštingumo lygiui ịvertinti naudotas išsamus 47 klausimų Sveikatos raštingumo tyrimo klausimynas HLS-EU-Q47, išverstas ị lietuvių kalbą [20]. Kitą anketos dali sudaro socialiniai demografiniai klausimai ir klausimai apie rūkymą. Statistiné analizè atlikta naudojant statistinių duomenų apdorojimo programas SPSS, Microsoft Excel ir WinPepi. Kategorinių duomenų analizei buvo naudojamas chi kvadrato $\left(\chi^{2}\right)$ kriterijus ir Fisher palyginimo testas. Dviems nepriklausomoms ranginėms imtims naudotas Mann-Whitney U testas, o kelioms nepriklausomoms ranginèms imtims - Kruskal-Wallis testas. Ryšiams tarp ranginių kintamųų nustatyti buvo naudojamas Spearmen koreliacijos koeficientas (rs). Rezultatai. Daugiau kaip pusès (53,3 proc.) mokinių sveikatos raštingumo lygis buvo pakankamas arba puikus, o kas 10 mokiniui nustatytas neadekvatus sveikatos raštingumo lygis. Berniukų ir 11 (III) klasių mokinių sveikatos raštingumas prastesnis, nei mergaičiu $(\mathrm{p}=<0,001)$ ir 12 (IV) klasių mokinių $(\mathrm{p}=<0,001)$. Penktadalis mokinių nuolat rūko. Rūkančių berniukų daugiau, nei mergaičių ( $p=<0,001)$. Nustatytos sąsajos tarp mokinių rūkymo ir sveikatos raštingumo: rūkančių mokinių, kurių aukštesnis sveikatos raštingumo lygis, yra mažiau, nei rūkančiųjų, kurių sveikatos raštingumo lygis žemesnis $\left(r_{s}=0,534, p<0,001\right)$.

\section{Ivadas}

Sveikatos raštingumas - dar nauja sveikatos stiprinimo koncepcija [1]. Jis suprantamas kaip gebejjimas ieškoti ir suprasti ịvairiais informacijos kanalais perduodamą informaciją apie sveikatą [2]. Sveikatos raštingumas susijęs su turimų žinių pritaikymu spręsti sveikatos problemas, žinių papildymu ir gebejjimu priimti tinkamus sprendimus sveikatos srityje.

Pasaulio sveikatos organizacija (toliau - PSO) $1998 \mathrm{~m}$. sveikatos raštingumą apibūdino kaip pažinimo ir socialinius igūdžius, lemiančius asmenų motyvaciją ir gebejjimą rasti, suprasti ir naudoti informaciją visais būdais, kurie skatina ir palaiko gerą sveikatą [3].

Sveikatos statistikos duomenys rodo vaikų sveikatos būklès prastėjimą. Nuo 2007 iki 2016 metų mokinių sergamumas padidejo 16,7 proc., o ligotumas $-15,5$ procentų. Kasmet šie rodikliai blogejja. Lietuvoje vaikai dažniausiai serga kvejpavimo sistemos ligomis, dažni regos, skeleto-raumenų ir kraujotakos sistemos sutrikimai [4]. Mūsų šalies vaikai jaučiasi gerokai nelaimingesni, negu kitų Europos šalių vaikai, blogiau vertina savo sveikatą [5]. Galima manyti, kad viena svarbiausių priežasčių yra tai, kad ilgą laiką mūsų šalyje sveikos gyvensenos kompetencijos ugdymui nebuvo skiriama pakankamai dėmesio, neịvertinamas vaikų sveikatos raštingumo lygis. Ribotas sveikatos raštingumas susijęs su blogesne sveikatos būkle [6] ir didesnèmis sąnaudomis. Pacientams ir šeimoms, kurios sunkiai supranta informaciją apie sveikatą, kyla sunkumų laikytis medicininių rekomendaciju, didesnè sveikatos problemu rizika.

Paauglystès laikotarpiu susiformavusi sveikatos elgsena turi poveikị suaugusiujų sveikatos rezultatams. PSO apibrèžia paauglystės tarpsni nuo 10 iki 19 metų [7]. Tyrèjai teigia, kad paauglystès laikotarpiu formuojasi socialinè, psicholo- 
ginè ir fizinè raida, požiūris ị vertybes, sveikos gyvensenos igūdžiai, gebejjimas suvokti savo sveikatą kaip svarbų gyvensenos aspektą $[8,9]$. Šiuolaikiniame greitai kintančiame pasaulyje paaugliai patiria daug sveikatos ir socialinių iššūkių. Daugelis paauglių sulaukia pilnametystès būdami geros sveikatos, o kiti - ne. Be to, daugelio suaugusiujjų sunkių ligų priežastis yra paauglysteje susiformavęs elgesys [10], todèl svarbu plètoti ir vertinti visuomenès sveikatos intervencijas, kurios skatintų geresni paauglių ir jaunimo sveikatos informacijos supratimą ir jos panaudojimą.

PSO jau seniai skelbia pavojų dẻl pastaruoju metu didèjančio vaikų ir paauglių rūkymo ir nikotino produktų vartojimo. Rūkymas ir toliau išlieka viena labiausiai paplitusių priklausomybių pasaulyje. Tarptautinio mokyklinio amžiaus vaikų gyvensenos ir sveikatos (Health behaviour in schoolaged children, toliau - HBSC) $2014 \mathrm{~m}$. tyrimo rezultatai parode, kad Lietuvoje 39 proc. 15 metų mergaičių ir 53 proc. berniukų pirmą kartą bandè rūkyti 13 metų ar jaunesni, bent kartą gyvenime rūkè 55 proc. mergaičių ir 70 proc. berniukų, 12 proc. mergaičių ir 20 proc. berniukų rūkẻ bent kartą per savaitę, bet ne kiekvieną dieną, o kiekvieną dieną rūkẻ 7 proc. mergaičių ir 14 proc. berniukų [11]. HBSC $2018 \mathrm{~m}$. tyrimas atskleide, kad 13 proc. 5-tų, 7-tų ir 9-tų klasių mokinių nuolat rūko, o 18 proc. rūko elektronines cigaretes [12]. Lietuvoje $2015 \mathrm{~m}$. vykdyto tarptautinio projekto Alkoholio ir kitų narkotikų vartojimas Europos mokyklose (The European school project on alcohol and others drugs, toliau-ESPAD) duomenimis, apie ketvirtadalis 15-16 m. paauglių rūko nuolat. Net 64 procentai 15-16 m. Lietuvos paauglių galètų lengvai ir labai lengvai ịsigyti cigarečių [13]. Lietuvos paauglių tabako vartojimas viršija Europos vidurkị [11]. Lietuvos mokyklinio amžiaus vaikų gyvensenos tyrimo duomenys parodè, kad per pastarąsias 30 dienų bent kartą rūkè tabako gaminius arba elektronines cigaretes 3,2 proc. penktoku, 10 proc. septintokų ir net kas ketvirtas (24,8 proc.) devintokas. Galima teigti, jog absoliuti dauguma pradeda rūkyti paauglystejje, nesuvokdami rūkymo padarinių. Šie sveikatos rodikliai, atspindintys vaikų ir paaugliu gyvenseną, rodo, kad labai svarbu didinti jų sveikatos raštingumą.

Tyrimų apie populiacijos sveikatos raštingumą atlikta labai mažai. Pirmasis tarptautinis sveikatos raštingumo tyrimas atliktas Europoje 2012 metais. Tyrimo duomenimis, beveik pusès Europos gyventojų nepakankamas sveikatos raštingumas [13]. Lietuvoje atlikta keletas suaugusiųjų sveikatos raštingumo tyrimų $[15,16]$, tačiau vaikų sveikatos raštingumas moksliniu aspektu pradètas gvildenti neseniai. Mokslinejje literatūroje pavyko rasti tik 2 šios problemos tyrimus $[17,18]$.

Tyrimo tikslas - nustatyti 11-12; III-IV klasių mokinių rūkymo ir sveikatos raštingumo sąsajas.

\section{Tyrimo imtis ir metodai}

Tyrimo imtis buvo sudaryta iš 11-12; III-IV klasių mokinių, kurie savo noru sutiko dalyvauti tyrime.

Imtis sudaryta sankaupos (klasterinès) atrankos būdu (tikimybinė atranka), atrankos vienetas (klasteris) buvo klasè. Siekta, kad atrinktieji atstovautu Lietuvos moksleiviams pagal lytį, amžių ir gyvenamają vietą. Buvo apskaičiuotas visu Lietuvos gimnaziju III-IV klasių ir pagrindinių ir viduriniu mokyklų 11-12 klasių skaičius, priskiriami klasterių numeriai eilès tvarka kiekvienai gimnazijai (mokyklai) ir, panaudojant atsitiktinių skaičių lenteles, atrinkta 40 klasių. Tokia imtis pakankama reprezentuoti Lietuvos gimnazijų III-IV klasių ir pagrindinių ir vidurinių mokyklų 11-12 klasių mokinių populiaciją.

Anoniminès anketinès apklausos metodu buvo apklausti 1038 mokiniai. Sveikatos raštingumo lygiui įvertinti naudotas išsamus 47 klausimų sveikatos raštingumo tyrimo klausimynas HLS-EU-Q47, išverstas ị lietuvių kalbą [20]. Ši priemonè pasirinkta dèl jos tinkamumo tirti paauglių sveikatos raštingumo lygi nuo 13 metų. Kita anketos dalis sudaryta tyrejų, kurioje pateikiami socialiniai demografiniai klausimai ir klausimai apie rūkymą. Klausimynas buvo išbandytas bandomojo tyrimo metu ir koreguotas, atsižvelgiant ị šio tyrimo rezultatus.

Mokinių apklausa buvo atliekama klasėse pamokų metu. Apklausos dieną mokykloje esantys mokiniai anketas pildè savarankiškai, pildymo laikas apie 20 minučių.

Apklausos dalyvių asmeniniai duomenys anketose nenurodyti. Duomenys iš medicinos kortelių tyrimui nebuvo naudojami. Visi atsakymų duomenys buvo koduojami ir suvesti ị tam tikslui sudarytą duomenų bazę. Analizuojami duomenys buvo apibendrinti visiems tiriamiesiems, rezultatai skelbiami laikantis tiriamųjų anonimiškumo ir konfidencialumo principų. Tyrimui atlikti gautas Vilniaus regioninio biomedicininių tyrimų etikos komiteto leidimas (2016-02-09 Nr. 158200-16-836-343).

Sveikatos raštingumui vertinti skirti 47 klausimai. Sveikatos raštingumui matuoti pasirinkta ranginè skalè: 1 - labai sunku, 2 - sunku, 3 - lengva, 4 - labai lengva. Respondentai galèjo pasirinkti atsakymą 5 - nežinau. Analizei buvo atrinkti tie respondentai, kurie atsakè į sveikatos raštingumo klausimus, pasirinkdami atsakymo variantus nuo 1 iki 4. Pasirinkę atsakymus „nežinau“, iš analizès buvo atmesti. Panaudojant atsakymo ị 47 klausimus balus, skaičiuotas bendrasis sveikatos raštingumo indeksas. Atsakymų balai buvo perskaičiuojami taip, kad mažiausias balas būtų lygus 0 , o didžiausias - 50. Sveikatos raštingumo indeksas skaičiuotas pagal formulę:

Indeksas $=($ vidurkis -1$) \times(50 / 3)$, kurioje:

vidurkis - kiekvieno respondento tam tikrų klausimų vidurkiai; 
1 - mažiausia galima vidurkio reikšmè (gaunama mažiausia indekso reikšmè - 0);

3 - vidurkiu plotis;

50 - pasirinkta maksimali indekso reikšmè.

Gautasis indeksas suskirstomas į 4 kategorijas ir vertinamas sveikatos raštingumo lygis: $0-25$ balai - neadekvatus raštingumas; 26-33 balai - probleminis raštingumas; 34-42 balai - pakankamas raštingumas; $43-50$ balai - puikus raštingumas $[19,20]$.

Statistinè analizė atlikta naudojant statistinių duomenu apdorojimo programas SPSS, Microsoft Excel ir WinPepi. Kategorinių duomenų analizei buvo naudojamas chi kvadrato $(\chi 2)$ kriterijus ir Fisher palyginimo testas. Dviems nepriklausomoms ranginems imtims naudotas Mann-Whitney U testas, o kelioms nepriklausomoms ranginèms imtims - Kruskal - Wallis testas. Ryšiams tarp ranginių kintamujų nustatyti buvo naudojamas Spearmen koreliacijos koeficientas (rs). Koreliacijos koeficiento verčių skalè: 0 - ryšio nèra, nuo 0 iki 0,2 - labai silpnas ryšys, nuo 0,2 iki 0,5 - silpnas, nuo 0,5 iki 0,7 - vidutinis, nuo 0,7 iki 1 - stiprus, 1 - labai stiprus ryšys. Tyrimo rezultatų skirtumai laikyti statistiškai reikšmingi, kai $\mathrm{p} \leq 0,05$.

\section{Rezultatai ir jų aptarimas}

Tyrime dalyvavo 1022 11-12; III-IV klasių mokiniai, iš jų 532 (52 proc.) merginos ir 490 (48 proc.) vaikinų (1 lentelè).

Siekta ịvertinti 11-12; III-IV klasių mokinių sveikatos raštingumo lygi, rūkymą ir nustatyti, ar yra ryšys tarp mokinių rūkymo ir jų sveikatos raštingumo.

1 lentelè. Respondentų charakteristikos.

\begin{tabular}{|l|c|c|c|c|c|c|}
\hline \multirow{2}{*}{ Klasė } & \multicolumn{2}{|c|}{$\begin{array}{c}\text { Vaikinai } \\
\text { (N=490) }\end{array}$} & \multicolumn{2}{c|}{$\begin{array}{c}\text { Merginos } \\
\text { (N=532) }\end{array}$} & \multicolumn{2}{c|}{$\begin{array}{c}\text { Iš viso } \\
\text { (N=1022) }\end{array}$} \\
\cline { 2 - 7 } & $\mathrm{N}$ & proc. & $\mathrm{N}$ & proc. & $\mathrm{N}$ & proc. \\
\hline $11(\mathrm{III})$ & 278 & 56,7 & 273 & 51,3 & 551 & 53,9 \\
\hline $12(\mathrm{IV})$ & 212 & 43,3 & 259 & 48,7 & 471 & 46,1 \\
\hline
\end{tabular}

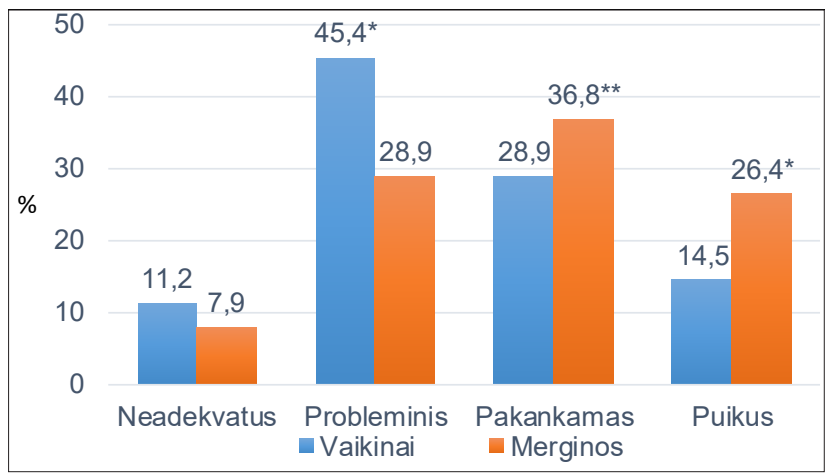

1 pav. Mokinių sveikatos raštingumo lygis pagal lytị. ${ }_{p}<0,001 ; * *_{p}<0,05$
Mūsų tyrimo duomenimis, daugiau kaip pusès (53,3 proc.) mokinių sveikatos raštingumo lygis buvo pakankamas arba puikus, kas 10 mokinio - neadekvatus. Pakankamas arba puikus sveikatos raštingumas dažniau nustatytas 12 (IV) klasių (68,6 proc.) nei 11 (III) klasių (41,4 proc.) mokiniams $(\mathrm{p}<0,001)$.

Analizuojant sveikatos raštingumą pagal respondentų lyti, nustatyta, kad mergaičių, kurių sveikatos raštingumas probleminis, yra mažiau (28,9 proc.), nei berniukų $(45,4$ proc.) $(\mathrm{p}<0,001), 1$ pav.

S. Šukys, L. Trinkūnienè ir I. Tilindienè (2019), atlikę pirmaji reprezentatyvų šios temos tyrimą Lietuvoje nacionaliniu mastu, žemą sveikatos raštingumą nustate 12,1 proc. 7-10 klasių mokinių. Tyrejjų duomenimis, 70,5 proc. mokinių sveikatos raštingumas yra vidutinis, o 17,4 proc. - aukštas [18]. Mūsų tyrimo rezultatai kiek geresni: 9,5 proc. 11-12 klasių mokinių sveikatos raštingumas yra žemas, o 20,4 proc. mokinių - puikus. Galima manyti, kad mūsų tyrimo rezultatai geresni dèl tyrime dalyvavusių vyresnio amžiaus mokinių. Be to, sveikatos raštingumas vertintas skirtingomis priemonèmis.

Analizuojant rūkymo dažni, nustatyta, kad kas ketvirtas mokinys rūko, daugiau kaip pusè (63 proc.) - nerūko, kiti (17

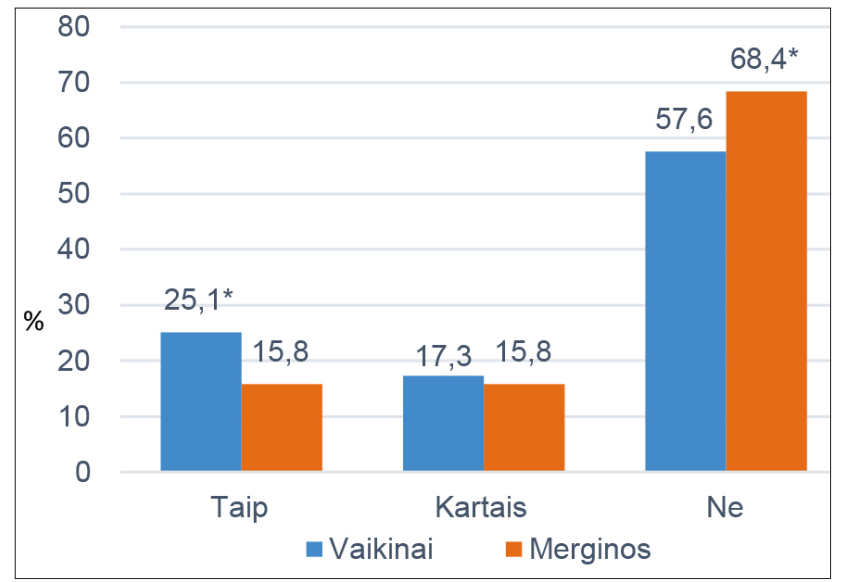

2 pav. Rūkančių ir nerūkančių mokinių pasiskirstymas pagal lytị. ${ }^{*} p<0,001$

2 lentelè. Mokinių rūkymo dažnis ir sveikatos raštingumo lygis. $r_{s}=0,534, p<0,001$

\begin{tabular}{|l|c|c|c|c|c|}
\hline Klausimas & $\begin{array}{c}\text { Atsa- } \\
\text { kymo va- } \\
\text { riantas }\end{array}$ & \multicolumn{4}{|c|}{ Sveikatos raštingumas } \\
\cline { 2 - 3 } & $\begin{array}{c}\text { vidutinis } \\
\text { rangas }\end{array}$ & $\chi^{2}$ & df & p \\
\hline \multirow{2}{*}{ Ar Tu rūkai? } & Taip & 174,93 & & & \\
\cline { 2 - 3 } & Kartais & 497,19 & \multirow{3}{*}{347,724} & 2 & $<0,001$ \\
\cline { 2 - 3 } & $\mathrm{Ne}$ & 616,15 & & & \\
\hline
\end{tabular}


proc.) rūko kartais. Rūkančių berniukų $(25,1$ proc.) statistišskai reikšmingai daugiau, nei rūkančių mergaičiu (15,8 proc.) $(\mathrm{p}<0,001)$. Visiškai nerūkančių daugiau mergaičių $(68,4$ proc.), nei berniuku (57,6 proc.) ( $\mathrm{p}<0,001), 2$ pav. Daugiau rūkančiųų yra 12 (IV) (19,1 proc.) nei 11 (III) (16,7 proc.) klasėse. Visiškai nerūkančių mokinių daugiau 11 (III) $(60,8$ proc.), nei 12 (IV) (59,7 proc.) klasèse, bet šis skirtumas pagal klases nèra statistiškai reikšmingas $(\mathrm{p}=585)$.

Lietuvos mokinių gyvensenos tyrimai rodo vis didejanti rūkymo ir nikotino produktų vartojimą tarp vaikų ir paauglių. HBSC tyrimo rezultatai parodè, kad 19 proc. 15 metu mergaičių ir 34 proc. berniukų rūkè bent kartą per savaitę arba kiekvieną dieną [5]. Mūsų tyrimo duomenimis, rūkančių mokinių daugiau: 42,4 proc. vaikinų ir 31,6 merginų rūko nuolat, arba kartais. Šie skirtumai gali būti susiję su tuo, kad mūsų tyrime dalyvavo vyresnio amžiaus mokiniai ir dèl skirtingo mokinių rūkymo dažnumo grupavimo.

ESPAD (2015) tyrimo duomenys parode, kad apie ketvirtadalis 15-16 m. Lietuvos paauglių rūko nuolat [13]. Mūsų tyrimas atskleide, kad nuolat rūko penktadalis 16-19 metu mokinių. Šie skirtumai taip pat gali būti susiję su mūsų tyrimo dalyvių vyresniu amžiumi.

Vertinant mokinių rūkymą, atsižvelgiant ị sveikatos raštingumo lygi, nustatytas statistiškai reikšmingas vidutinis tiesioginis ryšys (2 lentelè). Rūkančių mokinių žemesnis sveikatos raštingumo lygis, negu nerūkančių. Tarp dviejų požymių nustatytas statistiškai reikšmingas vidutinis tiesioginis ryšys (2 lentelè). Labai panašaus stiprumo koreliacinis ryšis tarp sveikatos raštingumo ir rūkymo gautas, lyginant šiuos merginų $\left(\mathrm{r}_{\mathrm{s}}=0,514, \mathrm{p}=<0,001\right)$ ir vaikinų $\left(\mathrm{r}_{\mathrm{s}}=0,575\right.$, $\mathrm{p}=<0,001)$ rodiklius, $\mathrm{o}$ taip pat lyginant tuos pačius $11 \mathrm{kla}-$ $\operatorname{sių~}(0,535, p=<0,001)$ ir 12 klasių mokinių $(0,540, p=<0,001)$ rodiklius.

Mūsų tyrimo rezultatai panašūs ị kitų tyrẻjų rezultatus. Kitų tyrimų duomenimis, beveik du kartus dažniau rūko nepakankamo sveikatos raštingumo (22,9 proc.) mokiniai, nei tie, kurių sveikatos raštingumas ịvertintas kaip pakankamas $(13,5$ proc.) $p<0,05$ [13]. Šis ryšys atskleidžia, kad nepakankamas sveikatos raštingumo lygis gali lemti rūkymo paplitimą, kuris gali prisidèti prie sveikatos būklès blogèjimo, tuo tarpu rūkymas ir kitas žalingas elgesys gali lemti nepakankamą sveikatos raštingumo lygị.

\section{Išvados}

1. Daugiau kaip pusès mokinių sveikatos raštingumo lygis buvo pakankamas arba puikus. Berniukų ir 11 (III) klasių mokinių sveikatos raštingumas blogesnis, nei mergaičiu ir 12 (IV) klasių mokinių.

2. Penktadalis mokinių rūko nuolat. Rūkančių berniukų yra daugiau, nei rūkančių mergaičių.
3. Nustatytos sąsajos tarp mokinių rūkymo ir sveikatos raštingumo: aukštesnio sveikatos raštingumo lygio rūkančių mokinių yra mažiau, nei rūkančių esant žemesniam sveikatos raštingumo lygiui.

\section{Literatūra}

1. Nutbeam D. Health literacy as a public health goal: a challenge for contemporary health education and communication strategies into the 21st century. Health Promot Int 2000;15:259-67.

2. Šveikauskas V. Sveikatos edukologija. Kaunas, 2008:31-38.

3. Health promotion glossary. World health organization 1998:10.

4. Sveikatos statistika. https://stat.hi.lt/

5. Health behaviour in school-aged children. A World health organization collaborative cross-national study. http://www. hbsc.org

6. Berkman ND, Sheridan SL, Donahue KE, Halpern DJ, Crotty K. Low health literacy and health outcomes: an updated systematic review. Ann Intern Med 2011;155:97-107.

7. Child and adolescent health and development..http://www.searo.who.int/entity/child_adolescent/topics/adolescent_health/ en/

8. Park MJ, Brindis CD, Vaughn B, Barry M, Guzman L, Berger A. Adolescent health highlight: health care services. Child Trends 2013.

9. Radzevičienė L., Vaitkevičius V.J., Mockevičienė D., Aleknavičiūtè-Ablonskė V., Dobrovolskytė I., Miliūnienè L., Navickienè V., Savenkovienė A. Paaugliu fizinis aktyvumas ir sveikata. Kaunas, 2016; 9-75.

10. Adolescent health. http://www.searo.who.int/topics/adolescent_health/en/

11. Inchley J, Currie D, Young T, et al. Growing up unequal: gender and socioeconomic differences in young people's health and well-being. Health Policy for Children and Adolescents 2016; 7(7):277.

12. Švietimo, mokslo ir sporto ministerija. Švietimo būklès apžvalga. Vilnius, 2019. http://birzuausra.lt/wp-content/ uploads/2019/01/HBSC-LT-sveikatos-tyrim\%C5\%B3med $\%$ C $5 \%$ BEiaga.pdf

13. ESPAD report 2015. Results from European school survey project on alcohol and other drugs. http:/www.emcdda.europa. eu/system/files/publications/3074/ESPAD_report_2015.pdf

14. Javtokas Z., Sabaliauskas R., Žagminas K., Umbrasaitè J. Suaugusių Lietuvos gyventojų sveikatos raštingumas. Visuomenès sveikata, 2013;4(63):38-46.

15. Zagurskienė D., Misevičienė I. Skirtingų sveikatos raštingumo lygių pacientų nuomonè apie slaugytojų teikiamą sveikatos informaciją. Kaunas, Medicina, 2010;46(1):27-34.

16. Sukys S, Cesnaitiene VJ, Ossowsky ZM. Is health education at university associated with students' health literacy? Evidence from cross-sectional study applying HLS-EU-Q. Biomed Res Int 2017 doi: 10.1155/2017/8516843.

17. Augustanavičienè O. Moksleivių sveikatos raštingumo ir gy- 
vensenos sąsajos. Magistro darbas. Kaunas, 2011.

18. Sukys S, Trinkuniene L, Tilindiene I. Subjective health literacy among school-aged children: first evidence from Lithuania. Int 2019. doi:10.3390/ijerph16183397

19. European health literacy consortium.Comparative report of health literacy in eight EU member states. The european health literacy survey LLSEU. 2012. https://www.healthliteracyeurope.net/hls-eu

20. Javtokas Z., Žagminas K., Žeromskienė D. Gyventojų sveikatos raštingumo vertinimas. Metodiniai patarimai. Vilnius, 2019. http://www.smlpc.lt/media/image/Naujienoms/2017\%20metai/ Lankstukai/Sveikatos_rastingumo_vertinimas.\%202017\%20 (1).pdf

\section{HEALTH LITERACY AND SMOKING OF 11-12 GRADES SCHOOLCHILDREN} O. Ubartienė, G. Šurkienė

Keywords: health literacy, adolescent, schoolchildren, health, smoking, health behaviour, addictions.

Summary

Background. Health literacy is an important and established area in public health. Limited health literacy is linked to worse health outcomes and higher costs. Adolescents need special attention, cause health behaviour developed during this period impacts health outcomes in adults. Therefore, it is important to develop and evaluate interventions that can promote a greater understanding and using health information for adolescent.

The aim of the study: To assess health literacy level and smoking of 11-12 grades schoolchildren.

Methods. Schoolchildren were questioned using anonymous survey method. The HLS-EU-Q47 comprehensive health literacy questionnaire of 47 items, translated into Lithuanian language, has been used to assess health literacy level. The respondents were also asked about socio-demographic characteristics, smoking status and other factors, which can be associated with health literacy. The statistical analysis were performed using the statistical data proces- sing program SPSS, Microsoft Excel and WinPepi. Chi-square criterion $\left(\chi^{2}\right)$ and Fisher's comparison test were used for categorical data analysis. For two unrelated ranked samples, the Mann - Whitney $U$ test was used, and for several unrelated ranked samples, the Kruskal - Wallis test was used. Spearmen correlation coefficient (rs) was used to determine the relationships between rank variables. Scale of correlation coefficient values: 0 - no relationship, 0 to 0.2 - very weak relationship, 0.2 to 0.5 - weak, 0.5 to 0.7 medium, 0,7 to 1 - strong, 1 - very strong relationship. The reliability coefficient of the survey was $p<0,05$.

Results. The data showed that more than half of schoolchildren (53,3 percent) manifested sufficient or excellent level of health literacy. One-fifth (20,4\%) of 11-12 grades schoolchildren has excellent health literacy and almost every tenth (9,5 percent) schoolchildren has low health literacy. The health literacy was lower for boys than for girls $(\mathrm{p}=<0.001)$, and lower for 11th graders than for 12 th graders $(p=<0.001)$. 68,6 percent of the 11 th graders and 41,4 percent $(p=<0.001)$ of the 12 th graders have sufficient or excellent health literacy. Analyzing student smoking, one in four (20,5 percent) schoolchildren smoke, 17 percent smoke sometimes, and 63 percent replied they did not smoke. There are more boys smoking than girls $(p=<0.001)$. Limited health literacy is associated with smoking addiction. Smoking schoolchildren have lower level of health literacy compared to non-smoking schoolchildren $\left(r_{s}=0,534, p=<0.001\right)$.

Conclusions. More than half of the schoolchildren manifested sufficient or excellent level of health literacy. The health literacy was lower for boys than for girls, and lower for 11th graders than for 12th graders. One fifth of schoolchildren smoke constantly. There are more boys smoking than girls. There is medium relationship between smoking and health literacy.

Correspondence to: olga.ubartiene@mf.vu.lt

Gauta 2019-11-15 